\title{
The Persistence of Reified Asia as Reality in Japanese Foreign Policy
} Narratives

\author{
Taku Tamaki $^{1}$ \\ School of Business and Economics \\ Loughborough University
}

\begin{abstract}
Asia is narrated in Japanese foreign policy pronouncements as an opportunity as well as a threat. Despite the purported transformation from militarism to pacifism since August 1945, the reified images of Asia as an 'entity out there' remain resilient. The image of a dangerous Asia prompted Japan to engage in its programme of colonialism before the War; and compels policy makers to address territorial disputes with Asian neighbours today. Simultaneously, Asia persistently symbolises an opportunity for Tokyo to exploit. Hence, despite the psychological rupture of August 1945, reified Asia remains a reality in Japanese foreign policy.
\end{abstract}

\footnotetext{
${ }^{1}$ Taku Tamaki is a Lecturer in International Relations in the School of Business and Economics at Loughborough University, UK. His work focuses on the intersection between International Relations Theory and Social Theory, as well as the role of identity in Japanese foreign policy and the international politics of the Asia-Pacific region. He is the author of Deconstructing Japan's Image of South Korea (Palgrave, 2010), and has published in journals including International Relations and the International Relations of the Asia-Pacific. He can be reached at T.Tamaki@lboro.ac.uk.
} 
Key Words: Japan; Asia; China; Foreign Policy; Identity; Narratives

\section{Introduction}

Despite the end of the Second World War, which saw prewar militarism superseded by postwar pacifism, Japan's outlook on Asia remains largely unchanged. Official Japanese narratives still display a sense of awkwardness about its Asian existence. The Japanese government's reaction to the resurgence of territorial disputes with its neighbours since the summer of 2012 reinforced the image of Asia as a potential threat-an idea reminiscent of the prewar interpretation of the international environment that prompted Japan to engage in its own programme of colonisation at the turn of the last century (Iriye 1991: 13-15). Simultaneously, Tokyo is keen to leverage the economic dynamism of Asia as a potential solution to its 'lost decades', providing another parallel to Japan's prewar Asia imaginary: that Asia is a source of opportunity indispensable to Japan's wellbeing. Hence, Asia remains a socially constructed entity that poses opportunities for Japanese leadership to exercise its selfproclaimed leadership role, on the one hand; but the legacies of the past and the concomitant absence of regional institutional structure means that Asia is understood as a dangerous place, on the other. In short, Asia remains a reified entity with multiple meanings for the Japanese leadership.

This poses a puzzle. Despite the purported changes in August 1945, there is a lingering image of Asian Otherness as an awkward 'thing out there'. What might explain the persistence of reified Asia in Japanese foreign policy narratives? And 
what implications does this have for Japan's foreign policy preference? ${ }^{2}$ The purported psychological rupture of August 1945 has not fundamentally changed Japanese leadership's outlook on Asia. On the contrary, Asia is reified into a dichotomous entity posing both a threat and opportunity within Japanese foreign policy narratives. Perhaps this is due to the international environment, such as the prewar Realpolitik, the Cold War environment in which Communist China became an important player, and the lingering animosities between Japan and its most immediate neighbours. It seems as if the change in Japanese identity has not moved in tandem with transformations in political economic challenges facing Japan. In short, 'opportunity' and 'threat' had become a default set of signifiers within Japanese foreign policy circles to 'talk about' international challenges facing Japan.

This article investigates how the Japanese constructions of Asian Otherness have reified Asia into a 'thing out there' to be identified as an opportunity as well as a threat in foreign policy narratives through the decades, and explores the implications for Japanese foreign policy today. The first section provides a brief overview of the main issues surrounding Japan's relations with Asia. The second section takes reification seriously, focusing on the possibility of reification as a social phenomenon with implications for policy outcomes. Reification matters, since it allows policy makers and theorists alike to talk about complex entities as tangible things to be studied and analysed. I argue that Asia has generally been reified into a notional entity with multiple meanings across the decades. However, it is also the case that the particular Japanese constructions of Asian Otherness have reified Asia into symbols that signify both an opportunity and a threat-a signifier that provides a frame of reference for contemporary Japanese foreign policy narratives. The third section

\footnotetext{
${ }^{2}$ I thank Linus Hagström for pointing out the 'puzzle'.
} 
explores the enmeshing of threat and opportunity in prewar Japanese foreign policy narratives, while the fourth section looks at the constructions of Asia during the Cold War. The fifth section investigates contemporary foreign policy narratives that reproduce the image of Asia as both an opportunity and a threat. The sixth section explores the implications for Japanese foreign policy. Japanese policy makers reify Asia the way they do because they need to be able to 'talk about' the challenges posed by the inherently complex region. This is why reification needs to be taken seriously.

\section{Japan and Asia}

Japan's geographical proximity to the Asian continent implies that Asia remains firmly within Japanese policy makers’ gaze. Yoon Keun Cha (1997: 176-77) notes that Asia constitutes a signifier that exemplifies Japan’s position as a 'non-Western' nation, while the perceived backwardness of Asia reinforced Japan's perceived uniqueness. Japanese elites in the $19^{\text {th }}$ century shared the view that a weak Asia was being devoured by the West, ultimately symbolising Asia’s purported 'backwardness'. This translated into the notion that Japan, which embarked on rapid modernisation following the Meiji Restoration of 1868, was superior to backward Asia (Yoon 1997: 79). As Takeuchi Yoshimi (1993: 294) notes, such hierarchicalised worldview also translated into a sense of camaraderie (rentai) between Japan and Asia.

In a similar vein, Iriye Akira (1966: 42-43) observes that 'prewar Japanese leaders thought Japan and China should co-operate to establish peace and prosperity in Asia, but witnessing China’s weakness, Japanese leaders also felt that Japan needed to establish itself as a leader (meishu) of Asia'. Japan's prewar militarism was underpinned by such an egotistical liberator identity compelled Japanese leadership to force change upon Asia (Iriye 1966: Chapter 6). Iriye (1991: 13-18) further notes that 
the prewar elites felt that the West and Japan were fundamentally irreconcilable, lending credence to the egotistical notion that Japan should lead the rest of Asia in its resistance against the West. Such views also encouraged intellectuals to justify the War as a war of liberation (Takeuchi 1979).

The prewar liberationist narrative was superseded by its postwar counterpart, in which a pacifist Japan was determined to pursue peaceful interdependence. Superficially, the prewar Japanese Self of egotistical liberator seems to have been superseded by a peaceful Japanese Self after the War. Yet, the indications are that Asia remains reified as symbolising Japan’s precarious position. Bert Edström (1999: 51) observes that 'Japan saw its role in Asia as a promoter of peace, as well as a bridge between the East and West'. Reflecting on Prime Minister Satō Eisaku's February 1970 speech, Edström (1999: 63) argues that,

\footnotetext{
The oldish view of Japan as excelling over Asia is seen in one statement Japan should build a base for a spiritually as well as materially rich national life in 'advance of all other countries in the world' as a country that was to excel over other Asian countries in the quest for welfare and prosperity. It was 'significant from the point of view of the history of the world civilization that such things should be realized by Japan, which is a member of Asia'.
}

Edström (1999: 146) notes that such a view continued into the post-Cold War period, with Prime Minister Kaifu Toshiki suggesting that Japan needed to be a spokesman for Asia, vis-à-vis, the 'West'. Hence, Asia remains a recurring theme in Japanese foreign policy narratives.

As Wakamiya Yoshibumi (2006: 121) states, 'Japan never felt it lost Asia. While the Western “enemies” evolved into “allies”, the sense of superiority towards Asia remained intact'. Glenn Hook, et al., (2012: 162) also suggest that '[the legacies of colonialism have] served as a structural barrier to distance Japan from closer political, economic and security ties with the region in the post-war era'. For them 
(2012: 163), 'the aftermath of the implosion of Japanese imperialism and the political space that it produced helped to create a geographical landscape conducive to the application of bipolarity and the emergence of a new Cold War order in the region'. Hence, within the Japanese policy elites' gaze, Asia remains an opportunity as well as a source of threat. According to Hook, et al., (2012: 232), Japan's defeat 'raised once again the international structural barrier of the legacy of colonialism to security interaction between Japan and the newly independent states of the region', and that,

\footnotetext{
Japanese policy makers themselves also remain reluctant to exercise leadership from the front; to exploit the opportunities of Asianism and internationalism to the full; and to endorse frameworks which could form an exclusive regional body centred upon Japan, and which would generate tensions with China, the US and other states in the region (Hook, et al. 2012: 252).
}

Therefore, Asia remains a notional entity for generations of Japanese policy makers to 'talk about' and reification is employed to expedite foreign policy making. The meanings attached to Asia might be ethnocentric and egotistical with a tinge of condescension. In any event, reified Asia is a product of Japan's exposure to the challenges posed by events in and around Asia.

\section{Reification as Social Reality}

The term reification is usually a curse in International Relations (IR) theorising, employed mainly to criticise fellow theorists for their failure to consider the complexities of social reality. The accusations and counter-accusations of reification have become more familiar in IR theory debates following the emergence of Constructivism and the subsequent turn to Metatheory and the Philosophy of Social Science (see Schiff 2008; Michel 2012; 2009; Kessler 2012). Yet, there is an important facet to reification: reification of social constructs enables social actors to 
talk about complex intangible entities as if they are identifiable things. While reification as part of an ontological commitment in theory-building might be controversial (Jackson 2011), there is nothing inherently wrong with applying this term to the psychological landscapes shared by practitioners, just as IR theorists share epistemological landscapes when they tell stories about the complexities of the international environment. In short, practitioners and theorists alike employ reification to render complex reality into workable models.

Humans employ reification as a way to navigate the complex social world (Searle 1995). As Colin Wight (2004: 270) puts it,

[reification of complex social reality] is so common place that it seems churlish to challenge it. After all, if social actors treat the state in this manner, what right have social scientists to question it?

A similar sentiment is shared by Benedict Anderson (1991: 59) who argues that symbols and ideas are reified into obdurate social facts that persist unless manipulated by significant external forces. In other words, however much the ideas of Asian Otherness may be a figment of collective imagination, such images do translate into policy making and implementation. In short, reification plays a vital role.

Examples of reified Asia in Japanese foreign policy narratives include Prime Minister Kishi Nobusuke stating in 1957 that, 'while Asia is not one, I did not think that Asia was divided into two groups [the Communists and the Free World]' (Kwon 2000: 177), as well as the Ministry of Foreign Affairs (MOFA) stating in 1970 that the 'situation in Asia is an admixture of stability and instability' (MOFA 1970: 74). In both cases, it was a way for the Japanese government to 'talk about' the complex region. To paraphrase Patrick Jackson (2011: xii; xiii), reification allows us to 'hook up to the world'. We need to bear in mind that policy makers actively reproduce reifications and they act on them. Hence, reification is not just a theoretical relic. As 
Rogers Brubaker and Frederick Cooper (2000: 5) argue, 'reification is a social process, not only an intellectual practice'. As such, reification is necessary if policy makers are to analyse macro-level social phenomena, including the international environment. The main function of reification is to make this process more bearable. Such reification should be taken seriously, since policy elites in Japan and elsewhere can only grasp the vast complexities by reifying Asia into a notional entity that means various things under various circumstances. In short, reification is part and parcel of international life, and it needs to be scrutinised if we are to appreciate the 'reality' encountered by policy elites.

\section{Reified Asia in Prewar Japan}

Asia as a diverse region provided a fertile platform upon which reification was employed to rationalise its inherent complexities. As a notional entity, as well as a geographical reality, prewar Japanese foreign policy narratives constructed Asia into a symbol denoting Japan's perceived vulnerability, as well as opportunities that needed exploiting. Asia has been imagined as a potential conduit for Western colonisers who were already 'devouring' China, as well as an object of desire in Japan's selfproclaimed identity as a 'liberator' and as a valuable source of resources. The variations in Japanese images of Asian Otherness derived from the various ways in which prewar policy elites in Tokyo attached meanings determined by the perceived diplomatic imperatives and national interests of the time.

\section{Threat and Opportunity Enmeshed}

Maruyama Masao (1961: 9) argues that the 'opening' (kaikoku) in the mid-1850s was tantamount to an exposure to the Realpolitik of Great Power rivalry. The decision to 
send troops to Taiwan in 1874, followed by an expedition to Korea in 1875, needs to be interpreted as an effort at addressing Japan’s purported security concerns. As Seki Shizuo (1999: 3) notes, while the political debate of 1873-75 revolved around whether or not to invade Korea, ultimately the issue was about the timing of Japan's Asia expedition, reinforcing the sense that Asia was a 'thing' to be desired and subjugated for the sake of Japan's own security. The purported 'punishment' of Taiwan and Korea in the 1870s, and the 'taming' of China following the Sino-Japanese War of 1894-95, represented Japan's increasing sense of vulnerability as a result of Asia's perceived weaknesses. Put differently, the policy elites felt that Asia required disciplining to prevent further exploitation by the West. Field Marshall Yamagata Aritomo, in his March 1890 memo to the government, argued for the delineation of a ‘sovereignty line’ (shuken sen) and the 'national interest line’ (rieki sen), defining the 'national interest line’ as ‘where our “sovereignty line” borders our neighbours'; and that the 'focal point of our rieki sen lies in none other than Korea' (Hirono 1999: 51). This highlighted the Japanese leadership's perception of Asia as a source of existential threat for Japan. The cabinet decision in 1903 reiterated such sentiment, arguing that 'our focus on the East Asian continent should be to maintain security of our Empire by encouraging Korean independence in the north and to bring the south of China, starting from Fujian, into our sphere of interest' (Iriye 1966: 39). Foreign Minister Komura Jutarō repeated this assessment in 1904 when he suggested that China was too weak to maintain its own autonomy (Iriye 1966: 39). Gotō Shimpei, the president of South Manchurian Railway, stated in July 1907 that it was important to 'encourage the powerful people in China (Shina no yūryokusha) to gain international awareness, and to convince them of the idea of Asia for the Asians as a 
way for them to understand the essence of Asianism' (Yamamuro 2001: 621). Thus, Asia was simultaneously a source of threat as it was an opportunity.

Similarly, Ugaki Kazushige, a former War Minister and Foreign Minister in the 1920s and the 1930s, considered China as a potential bulwark against further Western incursion. In his diary (December 1941), he argued that Japan should have 'tamed' (tenazukeru) China, and co-operated with it to push Soviet Union away from East Asia. Had Japan and China co-operated-and enhanced China’s capabilitiesthen this should have been possible. However, he also suggested that if this proved to be impossible, then force should have been employed (Matsuura 2010: 201-2). Ugaki also recognised that, so long as 'China's unification movement encompassed antiJapanese sentiments, then the survival of both Japan and China was at stake' (Tobe 1999: 249). For Ugaki, China was an opportunity intertwined with threat.

Matsui Ukon of the Imperial Army General Staff Office likened the SinoJapanese conflict to a sibling rivalry within the Asian household (Ajia no ikka): it was a way for the elder brother (Japan) to instil repentance on the younger brother (China) purely out of brotherly love (Matsuura 2010: 512). Similarly, Foreign Minister Ishii Kikujirō wrote in July 1931 that 'it is imperative that we use our holy interests as a shield with which to refuse pleasure to backward peoples' (Yamamuro 2001, 575), reiterating Japan's self-professed mission to civilise Asia. Even the liberal foreign minister, Shidehara Kijūrō, stated in August 1931 that 'our interests in Manchuria are inextricably linked to the activities of our nation, and however much we might be generous towards the Chinese government, we have no intention of forfeiting our rights and interests’ (Iriye 1966, 96). The August 1936 meeting of the prime minister, foreign- and finance ministers, as well as the army- and naval ministers stated that, 
Our continental policy centres on the healthy development of Manchukuo, along with the strengthening of Japan-Manchukuo security alliance. We will realise our economic development through strengthening the Japan-Manchukuo-China tripartite alliance, and by ridding the threat from northern Soviet Union, as well as preparing against the Americans and the British (Iriye 1966: 110).

It was this ethnocentricity which justified the War as brought about by the greed of the US and Britain, as stated in the Declaration of the Greater East Asian Conference in November 1943 (Harada 1975: 264). Hence, Asia was seen as a dangerous neighbourhood that made Japan vulnerable. Simultaneously, Japanese policy elites' confidence in considering Japan to be the most modern nation in Asia implied that Asia became synonymous with opportunity_an opportunity to realise Japan's leadership potential.

While the focus on Northeast Asia, and China in particular, elicited a sense of vulnerability and danger, Southeast Asia was merely seen as an opportunity. Colonel Watanabe Wataru of the Malayan Military Administration stated in May 1941 that,

\begin{abstract}
The indigenous peoples who had submitted themselves to the British rule for such a long time must be made aware of their need to reflect on their conduct and must be taught to endure hardship as citizens of Greater Asia for its prosperity. They can no longer be allowed to indulge themselves in a hedonistic and wasteful way of life that is eating up their mind and spirit.... The fundamental principle of my nationality policy is to require them to account for their past mistakes and to make them ready to give up their lives and property. Only when they repent their wrongdoing, will I allow them to live, and I will return their property once they repent (Akashi 2008: 39).
\end{abstract}

However much condescending such a view might have been, there was a fleeting sense of opportunity as well—an opportunity to turn purportedly backward people into acceptable subjects of the empire. In a similar vein, Marquis Tokugawa Yoshichika stated in June 1942 that 'Malays [should] be indoctrinated in the Japanese spirit to be the emperor's subjects, and pay a visit to Syonan [Singapore] Jinja enshrined with the ancestral god of their imperial family’ (Akashi 2008: 43). To be sure, these sound as if they were intended to camouflage the true intent of the 
Japanese government to exploit natural resources. General Okada Kikujirō asserted in November 1941 that 'what is most valuable for us in [Southeast Asia] is the oil' (Gotō 1995: 27). This was repeated in MOFA's Guidelines for Greater East Asia Strategy of May 1943 which explicitly stated that 'Southeast Asia provides crucial resources for the empire' (MOFA 2010b, 1486). Southeast Asia was an opportunity for the Japanese to turn its people into faithful subjects in the imperial project, and as a way to exploit resources. Effectively, Southeast Asia represented a hedge against the existential threat posed by Asia in general. Hence, Asia in prewar Japanese foreign policy narratives enmeshed threat and opportunity: because of the perceived threat emanating from Asia, it also became an opportunity for Japanese government to exploit it in the name of Japan's imperial project.

\section{Japan's Gaze on Asia During the Cold War}

The May 1950 MOFA document on economic relations called for pragmatism, stating that 'now that China was lost, it is Japan's destiny (unmei) to expand trade with Southeast Asia’ (Hatano and Satō 2007: 5-6). Superficially, Communist China may have been a threat during the Cold War, but the sense of danger was rather nuanced. As Prime Minister Yoshida Shigeru wrote to John Foster Dulles in December 1951,

The Japanese Government ultimately wants to establish trade and political relations with our neighbour China; and while it is in our best and realistic (genjitsu-teki de saizen) interest, we can guarantee that we have no intention of establishing bilateral relations with the People's Republic of China (Wakamiya 2006: 128).

Other policy makers shared similar optimism. Prime Minister Kishi Nobusuke stated in January 1958 that, 
Concerning Japan-China relations, the government has so far acted on the course of promoting trade and cultural exchange and of aiming at the solution of fishery and other problems to the maximum extent possible, given the present position of our country, and it wants to go on with this course. I hope and expect that both sides will come to understand each other's position where they have to conduct trade and cultural exchange in the present situation when national relations are not formally restored (Edström 1999: 43).

Hence, the threat of Communist China needs to be understood within the context of this latent pragmatism within Japanese foreign policy circles.

\section{Communist China as Threat and Opportunity}

The focus of Japanese foreign policy on Southeast Asia in the first two decades following the end of the War represented perceived threat, rather than opportunities, from China (MOFA 1957: 13). As early as 1953, Nakasone Yasuhiro warned that 'it is dangerous to hope for trade with China' given its close ties with the Soviet Union (Kanda 2013: 58). It is noteworthy that Yoshida himself mentioned similar intentions in November 1954, stating that 'Japan would strengthen its relations with Southeast Asian countries with the ultimate goal of strengthening the bulwark against "the Communist offensive”, (Edström 1999: 20). Kishi reiterated this position after visiting Southeast Asia in 1957, commenting on his willingness to 'talk to [the US] about what they are doing in Southeast Asia, and to discuss what Japan needs to do, given that the turmoil in Southeast Asia could precipitate a Communist invasion which would be detrimental to the world' (Wakamiya 2006: 135).

The MOFA had been forthright about the dangers of Communist China. Its 1960 Diplomatic Bluebook ${ }^{3}$ stated that, 'needless to say, we need to refute misunderstandings by the Chinese Communists. Yet, it is important for Communist China not to be arrogant' (MOFA 1960: 6). In the 1962 edition, MOFA stated that the

\footnotetext{
${ }^{3}$ While the name Diplomatic Bluebook (Gaikō seisho) did not appear until the 1980s, I will refer to the series of publications as Diplomatic Bluebook.
} 
Chinese membership of the United Nations 'poses potential danger (kiken) for the future, and therefore needs to be treated seriously’ (MOFA 1962: 19). Furthermore, the same issue noted that, 'depending on the way the [membership] issue is dealt with, it can seriously affect world peace, and thus is an extremely complex issue' (MOFA 1962: 20). Prime Minister Ikeda Hayato reiterated such sentiment in December 1962, stating that Communist China—and the march of Communism in Asia in generalmade pursuit of relations with the 'free countries' of Asia important; and that Japan needed to become 'a pillar of the "free camp" along with North America and Western Europe’ (Edström 1999: 53).

Eventually, the normalisation of Sino-American relations elicited a more positive outlook. MOFA’s Diplomatic Bluebook for 1974 (MOFA 1974: 126) stated that the normalisation of relations with China 'brings about an end to the 23 years of unnatural and abnormal relationship since the end of the War'. In the following year, MOFA (1975: 39) saw Indochina as representing the persistence of Communist threat in Asia, but the 'events in Asia have changed from confrontation to communication (taiketsu kara taiwa)', in a clear reference to Sino-Japanese rapprochement. There was an enhanced sense of optimism in the 1978 Diplomatic Bluebook, when MOFA (1978: 20) argued that 'good neighbourly relations between Japan and China hold significance for the peaceful international environment in Asia'. The change from threat to opportunity was defined primarily by international events. Nevertheless, it reveals that China still signified the duality of Asia as representing threat and opportunity for Japanese policy elites.

\section{Southeast Asia as an Opportunity}


To the extent Communist China represented a threat, Southeast Asia presented opportunities. As the MOFA Diplomatic Bluebook pointed out in 1959, while the relations with China remained sensitive (1959: 72-73), Southeast Asia was identified as the focal point of Japan's Asia diplomacy (MOFA 1959: 56). Not dissimilar to prewar Japanese interests in the region, MOFA stated in 1957 (1957: 23) that,

With their foodstuffs and raw materials necessary for sustaining our industries, Southeast Asian states remain important as sources of our imports. Furthermore, as important markets for our industrial products, their importance for the stability and prosperity of our postwar economy means that they are becoming increasingly indispensable.

A similar sentiment was repeated in 1958, when Southeast Asia was identified as an important region for the economic prosperity, as well as political stability, for Japan (MOFA 1958: 35)— an outlook that continued into the 1960s.

To a certain extent, the focus on Southeast Asia was borne of necessity. For Yoshida, Southeast Asia was effectively a 'substitute for the loss of Chinese market' (Edström 1999: 23-24). At the same time, the region was seen as a source of stability during the Cold War. Prime Minister Hatoyama Ichirō stated in January 1956 that the 'expansion of Japan’s economic relations with Southeast Asia [through] economic diplomacy (keizai gaikō) [was to become] the focal point of Japan’s Asia policy’ (Edström 1999: 33). The creation of Association of Southeast Asian Nations (ASEAN) in August 1967 enhanced the image of Southeast Asia as an oasis of stability. Speaking in December 1972, Foreign Minister Ōhira Masayoshi stated that '[o]ur intention is to join co-operative efforts with Southeast Asian states intent on forging stability and prosperity as a peace-loving member of Asia' (Tamaki 2013: 272). In the 1973 Diplomatic Bluebook for the same year, MOFA identified ASEAN as 'seeking to avoid unwanted external interference while strengthening autonomy', thereby contributing to the stability of Asia as a whole (Hatano and Satō 2007: 161). 
Thus, Asia as a whole continued to be narrated as an entity that posed challenges to Japan's interests, whether be it in the guise of national security or as a test of Japan’s postwar international legitimacy. Likewise, Southeast Asia provided a stark contrast to Northeast Asia yet again, depicting a region of relative stability and an important lifeline for Japan. In other words, the challenges of Cold War international politics resulted in the reproduction of a familiar dichotomy in Japan's images of Asia.

\section{Narrating the Reified Asia Today}

Contemporary Japanese foreign policy narratives continue to reproduce the dichotomous images of Asia as both an opportunity and a threat, though the stress is predominantly on the dangers posed by China since Summer 2012 as representative of the challenges Asia poses to the Japanese government. The 2014 Defence Whitepaper published by the Ministry of Defence (MOD) explicitly identified China as 'seeking to unilaterally change the status quo, potentially inciting crisis through escalation' (Nihon keizai shimbun 2014). For the Tokyo government, the reification of Asia into a set of challenges remains a default worldview through which the international environment is understood.

\section{Asia as Still a Threat}

Already back in 1969, a report by MOFA considered China to represent an 'eventual threat' symbolising dangerous Asia (Tanaka 1997: 220). This image was revisited in the mid- to late-2000s, when the Ministry of Defence (MOD) made explicit mentions of China's power projection capabilities. The National Institute for Defence Studies (NIDS) (2011: iii) published its China Security Report in 2011, stating that, while the 
Report did not reflect official views of the Japanese Government, the authors argued that they were compelled to analyse China's opaque military build-up. The 2009 East Asian Strategic Review, also published by the NIDS (2009: i), suggested that the 'maintenance of peace and stability in East Asia entails an objective understanding of the region's security environment', and such objectivity translated into identifying China as a main concern.

The territorial dispute over Senkaku/Diaoyu Islands that resurfaced in September 2010 reinforced that message. The 2011 edition of MOFA's Diplomatic Bluebook (2011: 17) stated that, 'there exist not only non-traditional threats, but also traditional threats in the East Asian region surrounding Japan. The year 2010 made it evident that the security of East Asia is still severe; and that situations remain indeterminate and unstable'. Considering the March 2010 sinking of a South Korean corvette, Cheonan, along with the North Korean shelling of Yongbyon Island in November that year, such pessimism was understandable. The Bluebook added that, 'while a rapidly developing China insists on a peaceful rise, their opaque military spending and maritime activities pose regional- as well as international concerns' (MOFA 2011: 17). These events reinforced the worldview shared among foreign policy elites that China and the Korean Peninsula still symbolised risks to Japan’s security—very similar to the threat perception at the turn of the last century (Iriye 1966: 30-32). In short, it was understood as the persistent reality of Japan’s Asian predicament.

Not surprisingly, the MOD was more pessimistic. Just as in other official publications, it recognised in its 2010 edition of the Defence White Paper that Asia was a rapidly expanding region, and as such, the region provided Japan with opportunities. However, it also suggested that, 'despite the end of the Cold War, 
conflicts and disputes remain; and while a dramatic shift in the security environment was experienced in Europe, there remain territorial, as well as unification, problems [in East Asia]' (MOD, 2010b: 3). The MOD (2010b: 3-4) went on to list perceived threats emanating from the familiar triad of Japan's security concerns-the Korean Peninsula, China, and Russia. It identified general concerns with respect to North Korea, as well as the opacity of Chinese military spending (MOD 2010b: 4), along with Russia’s military modernisation (Ibid.), arguing that, 'as such, the region still retains vague and indeterminate factors’ (Ibid.). Foreign Minister Asō Tarō reiterated this, stating that 'the problem remains China's military spending that is increasing annually at double-digit figures (nenkan futaketa no wariai). And there is absolutely no sense that it is transparent.... It is natural for neighbours to be alarmed by it. It would be unnatural if we kept quiet about it' (Chūō kōron 2006: 47). Similarly, Noda Yoshihiko (2011: 100), on the verge of taking over as the prime minister, admitted that, while Japan was heavily dependent on Chinese economy, he was also apprehensive about 'China's opaque military spending, along with its strategic thinking, [they] are both concerns not just for Japan, but also to other countries in the region. Recent, aggressive, Chinese foreign policy stance (taigai shisei) through military activities in the South China Sea potentially upsets the regional international order'.

Thus, China's military spending and modernisation defined Asia as a dangerous neighbourhood for Japanese foreign policy circles. The result was the further reproduction of the familiar reification of Asia into signifying threat for Japan. The then-leader of LDP, Tanigaki Sadakazu, suggested in 2010 that, well. Yet, China has a different face (betsu no kao) militarily. Its maritime and airborne operations pose concern for Japan and the surrounding countries. To pretend that we can 
maintain good relations with China and not worry about it can potentially endanger the security not just of Japan, but also of the Asia-Pacific region (Chūō kōron 2010: 137-38).

This sentiment was reiterated by Abe Shinzō on his second stint as the prime minister.

In a forthright interview with The Washington Post (2013) in February 2013, Abe argued that,

In the process of [patriotic education], in order to gain natural resources for their economy, China is taking action by coercion of intimidation, both in the South China Sea and the East China Sea. This is also resulting in strong support from the people of China, who have been brought up through this educational system that attaches emphasis on patriotism. This, however, is also a dilemma faced by China. That is to say, the mood and atmosphere created by the education in China attaching importance to patriotism — which is in effect focusing on anti-Japanese sentiment-is in turn undermining their friendly relationship with Japan and having an adverse effect on its economic growth. And the Chinese government is well aware of this.

While this did not constitute a conflation, per se, it represented Abe’s view that Asia remained dangerous because of China’s rise.

Hence, the psychological landscape shared by Japanese policy makers focused primarily on China as a source of threat for Japan's security. And it was China which seems to have represented Asia as a dangerous place. On the one hand, Asia still remained a threat because China made it so. As such, the security—and the larger international—environment has changed since the Cold War, let alone the turn of the last century. Yet, on the other hand, even if today's Japanese policy makers face issues that are different from the previous era, it seems that the reified image of Asia as symbolising threat has been recycled. In short, reified Asia remains relevant for policy makers in 'talking about' the changing international environment.

\section{Asia Remains an Opportunity}

Given Japan’s reliance on Asian and Chinese economies, it is not surprising that Asia is seen as the next growth centre holding the key to Japan’s own economic recovery. 
The MOFA (2010a: 20) stated in the 2010 edition of the Diplomatic Bluebook that the 'realisation of a prosperous, stable, and an open Asia-Pacific region is indispensable to Japan's peace, stability, and prosperity', and that the construction of the 'East Asian Community is a vital element' in this process, hoping that an increased 'intraAsian demand' (Ajia naiju) would help pull Japan out of its lost decade (Ibid.). In the 2011 edition, MOFA (2011: 25) reaffirmed the importance of Asian economy, stating that the 'Asia-Pacific region is increasingly becoming crucial for Japan-both politically and economically', and 'it is for this reason that Japan is determined to contribute to the prosperity of Asia; and to use Asia's vitality and demand (katsuryoku, juyō) as a stimulus for Japanese economy as well’. In a similarly optimistic language, the White Paper on International Economy and Trade published by the Ministry of Economy, Trade, and Industry (METI) focused on the opportunities posed by Asia. In its 2009 edition, METI (2009: 270) identified Asia as a ' $21^{\text {st }}$ Century growth-centre', in the hope of leveraging Asian 'wealth, trade, and investment for the benefit of Japanese employment and innovation', while the 2010 edition invoked the narrative of Asia again as a 'growth centre', suggesting that Japan needed to 'contribute towards Asia's growth as a way of leveraging our own economy’ (METI 2010: 156).

Foreign policy elites reconstruct the reified image of Asia as an opportunity. Asō stated in 2006 with a hint of condescension reminiscent of the prewar era that, 'until about 30 years ago, Asia was almost synonymous with poverty.... Now, I am quite optimistic about the Asian region in the medium- to longer term' (Chūo kōron 2006: 47). In a characteristic reification that leaves Asia under-defined, a former foreign minister, Okada Katsuya of the Democratic Party of Japan (DPJ), admitted in 2009 that the US-Japan alliance was important, but suggested that 'Asia is another area where we will need to focus our attention... We are fortunate to be located in 
Asia, where the economy is expanding' (Sekai 2009: 141). Reiterating the Trade White Paper, Okada argued that, ‘we need to realise Japan’s stability and prosperity within the East Asian Community (EAC). Enhancing the economic linkages can only be achieved within interdependence, so it is our policy to construct (kumitateru) our Asian diplomacy' (Ibid.). Here again, we witness the identification of dynamic Asia as a 'tool' to help stimulate Japanese economy.

Gemba Kōichirō, another former DPJ foreign minister, argued that 'a democratic, prosperous, and stable Asia is indispensable for Japan's national interest' (Gaikō 2012: 15), adding: 'we need to improve our domestic public sentiments (kokumin kanjō) in order to forge more mature Sino-Japanese relations, so that we can enhance our strategic partnership in establishing rules for the Asia-Pacific region' (Gaikō 2012: 17). For Gemba, the Sino-Japanese relationship epitomised Japan's relations with Asia. In a similar vein, Noda (2011: 100) stated that the 'world around us is changing. Our economic and political position in the Asia-Pacific is also changing. China is the engine for growth; and if China's development is harmonious with the international community, then that provides opportunities for Japan as well'. Here again, even the changing economic environment of the $21^{\text {st }}$ century elicited familiar recycling of reified Asia as an opportunity, once again highlighting the inherent dichotomy in the Japanese constructions of Asia as an entity 'out there'.

\section{Southeast Asia as a Beacon of Stability}

Southeast Asia is still perceived as an oasis of stability in the region, and the closer relations with ASEAN is seen as a counter-balance to the perceived instability of Northeast Asia. Prime Minister Obuchi Keizō, commemorating the $30^{\text {th }}$ anniversary of ASEAN in 1997, used the occasion to hold what was to become the ASEAN+3 
meetings (Wakamiya 2006: 238), representing how Southeast Asia provided diplomatic opportunity for Japan. The sense of opportunity was also highlighted in January 2002 by Prime Minister Koizumi Junichirō, who argued that in the $21^{\text {st }}$ century, Japan and ASEAN under the principle of "acting together and advancing together” should enhance co-operation and construct a community' (Sadakata 2011: 208).

The importance of stability in Southeast Asia has been a recurring theme in Japanese foreign policy narratives. The 2004 Diplomatic Bluebook suggested that 'it is important for Japan to co-operate with ASEAN for it to become a force for political and economic stability. Japan intends to enhance co-operation with ASEAN in an effort at contributing to the political and economic stability of Southeast Asia, as well as the wider East Asia’ (MOFA 2004: 56). For that purpose, MOFA claimed that ASEAN was an important partner (MOFA 2004: 59), while also noting that ASEAN was the largest destination for Japanese foreign direct investment (MOFA 2004: 59). Similar sentiments were reiterated in subsequent publications, with the 2006 edition highlighting the 30 years of 'ASEAN-Japan friendship’ (MOFA 2006: 47), arguing that the relationship is evolving into a 'strategic partnership' (MOFA 2006: 49). The 2007 Diplomatic Bluebook reaffirmed 'Japan to proactively support the stability of ASEAN (MOFA 2007: 37), while the 2008 edition identified 'ASEAN as the most important investment partner’ (MOFA 2008: 37). The 2009 Diplomatic Bluebook quoted Foreign Minister Kōmura Masahiko proclaiming that 'the development of Mekong is to the benefit of ASEAN; and the growth in ASEAN is beneficial to Japan' (MOFA 2009: 41).

Hence, Southeast Asia is consistently represented as an opportunity for Japan. As Hook, et al. (2012: 211), suggest, 
Japan at the start of the twenty-first century has worked hard to cement good relations with ASEAN and to realize many of the goals of the Fukuda Doctrine from the 1970s. However, it is important to note that Japan's proactivity towards ASEAN has been driven in large part by concerns that Japan's 'special relationship' with Southeast Asia is now increasingly threatened by the rise of China as a competitor for regional leadership.

This is not dissimilar to the focus on Southeast Asia in the decades following the War.

Southeast Asia remained an opportunity, precisely because Asia, and China in particular, remained a dangerous neighbourhood.

\section{The Implications of Reified Asia}

The recent territorial conflicts since 2010 prompted the Japanese government to adopt a sterner language. Before the landslide victory by the LDP in both the December 2012 and July 2013 elections, the preceding DPJ government revised the National Defence Programme Guidelines (Bōei taikō) and the Midterm Defence Programme (Chūkibō) in December 2010, over concerns that the security environment was deteriorating. The Chief Cabinet Secretary, Sengoku Yoshito, referred to the need for enhancing defence capabilities, given the heightened tensions (MOD 2012c), while the Defence Minister, Kitazawa Toshimi, stated that,

\footnotetext{
With the existence of military power with nuclear capabilities, along with many states modernising their military power, the time has come for us to move from passive deterrence (seiteki yokushi) in which we rely solely on existing defence capability, to a more dynamic deterrence (dotteki yokushi) in which we show national determination (kokka no ishi) and a high level of defence capability (takai bōei nōryoku) on a continuous basis (MOD 2012b).
}

The Bōei taikō itself stated that the balance of power had shifted, and that many states are modernising their military, before explicitly naming North Korea, China, and Russia as involved in such activities (MOD 2010a: II-2). The Chūkibō augmented this by arguing for the necessity of strengthening response capabilities, particularly in the 
Southwest islands, including the deployment of radars and reconnaissance aircraft, along with transport helicopters (MOD 2012a: III-1(2)). Furthermore, the MOD (2012a: III-4(1)) stated that it was crucial to reorganise the command structure so that 'multiple events' (fukugō jitai) can be addressed swiftly through the implementation of joint command.

Following the change of government in December 2012, the new LDP administration initiated a review of the defence budget. Citing new developments, the Abe cabinet decided in January 2013 to abandon the 2010 Chükibō, explicitly referring to repeated territorial infringement by the Chinese, while reiterating the necessity of enhancing defensive capacity in the Southwest islands (MOD 2013b). As Abe noted in the February 2013 Washington Post (2013) interview,

Accordingly, for the first time in 11 years, I have increased our defense budget, as well as the budget for the Japan coast guard. It is important for us to have them [China] recognize that it is impossible to try to get their way by coercion or intimidation.

It is noteworthy that the reified notion of Asia as a dangerous neighbourhood is represented yet again within the Defence Posture Review Interim Report, which identified North Korea, China, and Russia as main concerns-again similar to the prewar sense of vulnerability (MOD 2013a).

It is within this context that the debate over collective self-defence had been revisited. The sense of Asia as a dangerous neighbourhood was repeated in an interview given by Kitaoka Shin'ichi, chairman of the committee tasked with assessing the legal framework for collective self-defence. In the interview, Kitaoka suggested that 'there is a country with nuclear arms that infringe our territorial waters. Unless Japan invests in its own nuclear weapons programme, there is no way Japan can fend for itself', adding that 'the times have changed; and the weapons technology 
is constantly evolving. With the rise of China and North Korea, can we work within the [old] rules [as prescribed by Article 9 of the Constitution]?' (Asahi shimbun 2013). Defence Minister Onodera Itsunori denied that collective self-defence is about sending troops abroad, but as if to prepare for an armed conflict with China over the Senkakus/Diaoyus, he pointed out instead that there was the need to debate what Japan should do if US warships trying to defend Japan came under attack in high seas-ostensibly helping to protect Japanese territory from Chinese invasion (Nihon keizai shimbun 2013). Another manifestation of this sense of danger is the launch of the new helicopter destroyer Izumo. Inoue Hisao (2013) interprets this as a natural response to Chinese naval activities around the East China Sea, commenting that possessing a helicopter carrier would be useful in enhancing the control of the airspace. This assessment is similar to an analysis by Kyle Mizokami (2013), suggesting that 'the Izumo and the rest of Japan's amphibious and helicopter escort ships could theoretically provide air and sea lift to transport Japan’s nascent marine infantry, the Western Army Infantry Regiment based in Southern Japan’—something that is reflected in the Bōei taikō and the now-abandoned Chūkibō.

The government in Tokyo is not yet actively preparing for war. However, the rhetoric seems to suggest that the officials are compelled to pronounce Japan's readiness to do so. Indeed, Abe told The Wall Street Journal (Baker and Nishiyama 2013) in October 2013 that, 'I’ve realized that Japan is expected to exert leadership not just on the economic front, but also in the field of security in the Asia-Pacific', warning that if China 'opts to [change the status quo by force], then it won't be able to emerge peacefully'. And such words precipitate a vicious circle of invectives that might instantiate an actual conflict. As Linus Hagström (2012: 297) argues, the narrative emphasising 'Chinese aggressiveness' has agency precisely 'because the 
more dominant it becomes the more inevitable it is that other states will take recourse to potentially dangerous balancing behaviour vis-à-vis China’. In a similar vein, we can argue that Japan's reification of Asia into a dangerous neighbourhood embodies a potential for self-fulfilling prophecy. Japan's contemporary foreign policy narratives view Asia, and China in particular, with a significant amount of scepticism, interpreting China's rise as 'detrimental to the security of the seas around China (Chūgoku wo torimaku kaiyō no anzen-hoshō kankyō ni hitei-teki na eikyō), and the areas around East Asia are no exception' (NIDS 2011: 44). These images of Asia and China conspire to complete the vicious circle in which the reified Asian Otherness representing threat trumps symbols of opportunity, thereby reinforcing the sense of Japan under siege.

\section{Conclusions}

Tokyo is constantly reminded of the fact that its existence is inextricably intertwined with events in Asia. For Japan situated in the eastern-most edge of Asia, Asia ceases to be a mere geographical designation: it constitutes a reality. Yet, there are multiple realities in that Asia poses both an opportunity as well as a potential threat. From a simple geographical perspective, it is not surprising. Japan cannot wish away neither the nuclear weapons of North Korea, nor territorial disputes with China and South Korea. Simultaneously, Asia provides opportunities, if not a lifeline, for Japan that is lacking in natural resources, as well as a possible solution to its economic problems. Hence, Asia remains a reified social construct that signify both an opportunity and a threat. Such narratives are becoming more salient following the flare-up in territorial disputes between Tokyo and its neighbours. 
The answer to the puzzle of resilient reification seems to lie with the international environment. The consistent reification of Asia into a set of signifiers by generations of Japanese policy elites points to its resilience in providing a continuous psychological landscape for understanding the constraints encountered by the Japanese government. To be sure, reified Asia might be a figment of imagination within the minds of policy makers. Yet, it is precisely due to the policy implications of such social constructs that reified Asian Otherness has remained potent throughout the decades. Put differently, even if Japanese identity had transformed since August 1945, the basic constraints of the international environment seems to have persisted in the minds of Japanese policy makers. The Korean peninsula remains unstable as a byproduct of the Cold War; China still represents both a threat and opportunity for Japan; and Southeast Asia represents a friendly sphere for Japan in stark contrast to the dangerous Northeast Asia. And in order to address these challenges, Asia has been reified into a familiar dichotomy of threat and opportunity. In short, Japanese foreign policy elites recycled the images of Asia to be able to 'talk about' and 'deal with' the complexities of international life in East Asia. Reification enabled Japanese policy makers to formulate and execute policies including recasting military capabilities to address mounting tensions with China, while identifying Asia as a source of economic salvation. These reified images prompted policy makers to take action, and this is the reason why reifications must be said to possess policy implications. To that effect, we need a better handle on reification. Without such an insight, Japanese debates on constitutional amendment, as well as the new thinking on the future defence of the Southwest islands, cannot be fully appreciated. After all, Japan's actions to counter China's rise are 'rational' insofar as they are contextualised within the narratives of reified Asia. The debates on collective self-defence and the launch of the helicopter 
destroyer are facets of the Japanese Self responding to the meanings attached to the narratives of Asian Otherness.

Hence, reifications are important. Japanese policy makers act on these perceptions. It means that Asia remains an awkward entity for Japan, and despite the narratives such as 'Japan in Asia', the two can never be synonymous, providing a particular template for the formulation of a particular policy preference. As such, Asia remains a 'thing out there' within Japanese policy narratives. Throughout the centuries of Japan's socialisation process in and around Asia, the foreign policy narratives suggest that Tokyo never identified itself fully with Asia, consistently utilising Asia as a signifier for Japan to proclaim itself as neither Western nor Asian. Hence, Asia remains a 'thing' that is potentially dangerous, but also a 'thing' that is beneficial for Japan. It is to be hoped that the events since the summer of 2012 do not portend a resurgence of Japanese narratives that marked the decades leading up to the 1930s and the 1940s.

\section{Acknowledgements}

I am extremely grateful to Linus Hagström for his piercing and insightful comments throughout the drafting of this article. I also thank the reviewers and the participants at Focus Asia: Collective Memory, Identity and International Relations in East Asia, Lund University, 6-7 November 2012, for their helpful comments on the earlier versions of this article.

\section{References}

Akashi Y. (2008) 'Colonel Watanabe Wataru: The architect of the Malayan Military Administration, December 1941-March 1943’, in Akashi Y. and Yoshimura M. 
(eds) New Perspectives on the Japanese Occupation of Malaya and Singapore, 1941-1945, Singapore: NUS Press, chapter 2.

Anderson, B. (1991) Imagined Communities, London: Verso.

Asahi shimbun (2013) 'Senshu-bōei towa "kōgeki zero" denai: Kitaoka zachō-dairi ichimon-itto’ [An exclusively self-defence policy is no “zero offensive”: Q\&A with Vice Chairman Kitaoka], 10 August; accessed at http://digital.asahi.com/articles/TKY201308090428.html?ref=comkiji_txt_end _kjid_TKY201308090428, 9 August 2013.

Baker G., and Nishiyama, G. (2013) ‘Abe says Japan ready to counter China's power: Premier urges China to refrain from using force', The Wall Street Journal, 26 October; accessed at http://online.wsj.com/news/articles/ SB10001424052702304799404579157210861675436>, 31 October 2013.

Brubaker, R. and Cooper, F. (2000) 'Beyond “Identity”', Theory and Society 29(1): 147.

Chūō kōron (2010) ‘Ajia no "kōkyō-zai” Nichibei-dōmei wo kijuku ni hoshu-seiji wo saisei suru’ [Reviving conservative politics based on US-Japan alliance as Asia’s 'public good'], March, pp. 136-45.

(2006) 'Kore ga gaikō no hinkaku da' [This is the dignity of diplomacy], July, pp. 36-47.

Edström, B. (1999) Japan's Evolving Foreign Policy Doctrine: From Yoshida to Miyazawa, London: Macmillan.

Gaikō (2012) 'Nichi-bei-chū taiwa no toki' [The time for Japan-US-China trilogue], Vol. 11, January, pp. 12-21. 
Gotō K. (1995) Kindai Nippon to Tōnan-ajia: Nanshin no 'shōgeki' to 'isan' [Modern Japan and Southeast Asia: The 'Shock' and 'Legacies' of Southern Policy], Tokyo: Iwanami shoten.

Hagström, L. (2012) “"Power shift” in East Asia? A critical reappraisal of narratives on the Diaoyu/Senkaku Islands incident in 2010', The Chinese Journal of International Politics 5: 267-97.

Hatano S. and Satō S. (2007) Gendai Nippon no Tōnan-Ajia seisaku (1950-2006) [Modern Japan's Southeast Asian Policy (1950-2006)], Tokyo: Waseda daigaku shuppanbu.

Harada K. (1975) Dokyument Shōwa-shi 4: Taiheiyō-sensō [Document History of Showa 4: The Pacific War], Tokyo: Heibonsha.

Hirono Y. (1999) 'Yamagata Aritomo: "Yamagata Aritomo Ikensho”' ['Yamagata Aritomo: "The Opinion of Yamagata Aritomo"'], in Seki S. (ed.), Kindai Nippon gaikōshisō-shi nyūmon [Introduction to Modern Japanese Diplomatic Thought], Kyoto: Minerva, chapter 3.

Hook, G. D., et al. (2012) Japan’s International Relations: Politics, Economics and Society ( $3^{\text {rd }}$ ed.), London: Routledge.

Inoue H. (2013) ‘Hiroshima genbaku no hi, kubo-gata goeikan "Izumo” no meimei shinsuishiki ni omouno wa “heiwa-boke” Nippon’ [Pondering Japan’s peacenumbness on the day of destroyer Izumo’s launch], Gendai bijinesu [Contemporary Business], 8 August 2013; accessed at <gendai.ismedia.jp/articles/print/36653>, 9 August 2013.

Iriye A. (1991) Shin Nippon no gaikō [New Japan’s Diplomacy], Tokyo: Chūkō shinsho. (1966) Nippon no gaikō [Japan’s Diplomacy], Tokyo: Chūkō shinsho. 
Jackson, P. T. (2011) The Conduct of Inquiry in International Relations, London: Routledge.

Kanda Y. (2013) '1980-nendai no reisen to Nippon gaikō ni okeru futatsu no chitsujokan: Nakasone-seiken no tai-Chū gaikō wo juku toshite' ['Two Conceptions of Order During the Cold War of the 1980s and Japanese Diplomacy: Focusing on Nakasone Cabinet’s China Diplomacy’], Ajia-taiheiyō tōkyū [Asia-Pacific Research] 19: 53-69.

Kessler, O. (2012) 'On logic, intersubjectivity, and meaning: is reality an assumption we just don’t need?', Review of International Studies 38(1): 253-65.

Kwon Yongseok (2000) 'Kishi no Tōnan-ajia rekihō to “tai-bei jishu” gaikō’ [Kishi’s Southeast Asia tour and “autonomous diplomacy” against the US], Hitotsubashi ronsō [Hitotsubashi Papers]123(1): 170-89.

Maruyama M. (1961) Nippon no shisō [Japanese Thought], Tokyo: Iwanami shinsho. Matsuura M. (2010) 'Dai-tōa sensō' wa naze okita noka: Han-ajia-shugi no seiji kiezai-shi [Why the 'Great Far Eastern War' Happened: The Political Economic History of Pan-Asianism], Nagoya: Nagoya daigaku shuppankai.

Michel, T. (2012) ‘In Heidegger’s shadow: a phenomenological critique of critical Realism', Review of International Studies 38(1): 209-22. (2009) 'Pigs can’t fly, or can they? Ontology, scientific realism and the metaphysics of presence in international relations', Review of International Studies 35(2): 397-419.

METI (2010) Tsūshō hakusho 2010 [The Trade White Paper], Tokyo: METI. (2009) Tsūshō hakusho 2009, Tokyo: METI. 
Mizokami, K. (2013) 'Japanese “helicopter destroyer” stirs regional tensions’, USNI News, 12 August; accessed at news.usni.org/2013/08/12/japanese-helicopterdestroyer-stir-regional-tensions?utm_source=feedly, 15 August 2013.

MOD (2013a) Bōeiryoku no arikata kentō ni kansuru chūkan hōkoku [Interim Report on the Defence Capability], 26 July 2013, Tokyo: MOD. (2013b) Heisei-25nendo no bōeiryoku seibi tō ni tsuite [Upgrading Defence Capabilities for FY 2013], 25 January 2013, Tokyo: MOD. (2012a) Chūki bōeiryoku seibi keikaku (Heisei 23-nendo kara Heisei 27-nendo) ni tsuite [Mid-term Defence Planning for FY2011-FY2015], 17 December 2012, Section III-1 (2), Tokyo: MOD. (2012b) 'Heisei 23-nendo ikō ni kakawaru bōei keikaku no taikō’ oyobi 'Chūki bōeiryoku seibi keikaku (Heisei 23-nendo kara Heisei 27-nendo)' no kettei ni tsuite [Decisions on the Defence Programme Guidelines for FY2011 and Beyond; and the Mid-term Defence Guidelines for FY2011-FY2015], 17 December 2012, Tokyo: MOD. (2012c) Naikaku kanbō chōkan danwa [Statement by the Chief Cabinet Secretary], 17 December 2012, Tokyo: MOD. (2011) Nippon no bōei 2011 [The defence of Japan], Tokyo: MOD. (2010a) Heisei 23-nendo ni kakawaru bōei keikaku no taikō [Mid-term Defence Guidelines for FY 2011], 17 December 2010, Section II-2, Tokyo: MOD. (2010b) Nippon no bōei 2010, Tokyo: MOD.

MOFA (2011) Gaikō seisho 2011 [The Diplomatic Blue Book], Tokyo: MOFA. (2010a) Gaikō seisho 2010, Tokyo: MOFA. (2010b) Nippon gaikō monjo: Taiheiyō-sensō dai-ni satsu [Documents on Japanese Foreign Policy: The Pacific War, Second Volume], Tokyo: MOFA. 
(2009) Gaikō seisho 2009, Tokyo: MOFA.

(2008) Gaikō seisho 2008, Tokyo: MOFA.

(2007) Gaikō seisho 2007, Tokyo: MOFA.

(2006) Gaikō seisho 2006, Tokyo: MOFA.

(2004) Gaikō seisho 2004, Tokyo: MOFA.

(1985) Gaikō seisho FY 1984, Tokyo: MOFA.

(1978) Waga gaikō no kinkyō FY1977 [The State of Our Diplomacy], Tokyo:

MOFA.

(1975) Waga gaikō no kinkyō FY1974, Tokyo: MOFA.

(1974) Waga gaikō no kinkyō FY1973, Tokyo: MOFA.

(1970) Waga gaikō no kinkyō FY1969, Tokyo: MOFA.

(1962) Waga gaikō no kinkyō June 1962, Tokyo: MOFA.

(1960) Waga gaikō no kinkyō June 1960, Tokyo: MOFA.

(1959) Waga gaikō no kinkyō March 1959, Tokyo: MOFA.

(1958) Waga gaikō no kinkyō March 1958, Tokyo: MOFA.

(1957) Waga gaikō no kinkyō September 1957, Tokyo: MOFA.

NIDS (2011) Chūgoku anzen-hoshō repōto 2011 [China Security Report], Tokyo:

NIDS.

(2009) Higashi-Ajia senryaku gaikan 2009 [East Asia Strategic Review],

Tokyo: NIDS.

Nihon keizai shimbun (2014) "Anpo kankyō "yori shinkoku ni”" [Security Environment Becomes Even More Severe], 5 August, p. 1.

(2013), 'Bōei-shō, shūdan-teki jiei-ken "kaigai-hahei ni tusnagarazu”,

[Collective self defence will not lead to troop deployment overseas, Defence

Minister],

17

August;

accessed

at 
http://www.nikkei.com/article/DGXNASDE17001_X10C13A8NNE000/, 19 August 2013.

Noda Y. (2011) 'Waga seiken kōsō’ [My policy plan], Bungei shunjū [Literary Times], September, pp. 94-103.

Sadakata M. (2011) 'Higashi-Ajia chiiki-shugi no kanōsei to Nippon gaikō' [The Possibility of East Asian Regionalism and Japanese Diplomacy], Nagoyadaigaku hōsei ronshū [Nagoya University Law Papers] 239: 203-25.

Sekai (2009) ““Ajia no naka no Nippon” to shite anzen-hoshō seisaku wo kōchiku shinakereba naranai' [The need to establish defence policy for Japan in Asia], July, pp. 138-43.

Schiff, J. (2008) “'Real”? As if! Critical reflections on state personhood’, Review of International Studies 34(2): 363-77.

Searle, J. (1995) The Construction of Social Reality, London: Penguin.

Seki S. (1999) 'Introduction’ in Seki S. (ed), Kindai Nippon gaikō shisō-shi nyūmon [Introduction to Diplomatic Thought in Modern Japan], Kyoto: Minerva, Introduction.

Takeuchi Y. (1993) Nihon to Ajia [Japan and Asia], Tokyo: Chikuma gakugei bunko. (1979), ‘Kindai no chōkoku’ [Overcoming modernity] in Kawakami T., et al., Kindai no chōkoku, Tokyo: Fuzan shobō, pp.273-347.

Tamaki K. (2013) 'Shoki ASEAN no seichō to Nippon: futatsu no tai-Nichi atsuryoku’ ('Early Development of ASEAN and Japan: Two Pressures on Japan’), Ajia-taiheiyō tōkyū (Asia-Pacific Research), 20: 269-76.

Tanaka A. (1997) Anzen hoshō: Sengo 50-nen no mosaku [National Security: 50 Years of Postwar Contemplation], Tokyo: Yomiuri shimbun. 
Tobe R. (1999) ‘Ugaki Kazushige, “Ugaki Kazushige nikki”’ [Ugaki Kazushige diaries], in Seki S. (ed), Kindai Nippon gaikō shisō-shi nyūmon, Kyoto: Minerva, chapter 15.

Wakamiya Y. (2006) Wakai to nashonarizumu (Reconciliation and Nationalism), Tokyo: Asahi shimbunsha.

The Washington Post (2013) 'Transcript of interview with Japanese prime minister Shinzo Abe’, 20 February; accessed at http://www.washingtonpost.com/world/transript-of-interview-with-japaneseprime-minister-shinzo-be/2013/02/20/e7518d54-7b1c-11e2-82e861a46c2cde3d_story.html, 22 February 2013.

Wight, C. (2004) 'State agency: social action without human activity?’, Review of International Studies 30(2): 269-80.

Yamamuro S. (2001) Shisō-kadai to shite no Ajia: Kijuku, rensa, tōki [Asia as a Thought-Issue: Focal Point, Linkage, Project], Tokyo: Iwanami shoten. Yoon K. C. (1997) Nippon kokumin-ron: kindai Nippon no aidentitī [Japanese Nation: Identity in Modern Japan], Tokyo: Chikuma shobō. 